\title{
Sustainability in the New Business of Business: From Control to Self Control in Leadership
}

\author{
Krishna Chandra Mishra \\ No. 1336/23, $1^{\text {st }}$ Cross, Nanjamma Layout, Manorayanapalya, \\ R.T Nagar Post, Bangalore - 560032, Karnataka, India
}

Tel: 91-91-1392-2289. E-mail: mishrakc847@gmail.com

Received: October 20, 2018 Accepted: December 10, 2018 Published: December 13, 2018 doi:10.5296/jpmr.v4i2.14051

URL: https://doi.org/10.5296/jpmr.v4i2.14051

\section{Introduction}

Many theories are evolved in economics and management to explain the imbalance in demand and supply of goods and services or consumption pattern, resource allocation, and so on. All these theories explain a common fact, competition to acquire resources to maximize wealth. All the wars the human race fought in the past were for one purpose, to acquire and accumulate wealth. In all these, few stakeholders of the universe are ignored: human beings, environment, earth and other living creatures on earth. Deep deforestation and overuse of natural resources have questioned the survival of mankind itself. How long the greed and competition for unquestionable global leadership will go on and what would be the fate of unprivileged in these? Can their survival be challenged? Can we think an alternative inclusive paradigm for management to ensure justice to everything on earth to survive peacefully? Yes we can, through a spiritual leadership for sustainable growth and business.

\section{Spirituality: The Core of Everything}

Peter Pruza says spirituality is the search for meaning that transcends material well-being. It searches for basic, fundamental human values and an association with a universal power called divinity. When we focus on possibilities we have more opportunities; life is the truest opportunity so let's navigate the same to experience both body and the existence to be comfortable. Information and Technology are important but for the essential things of life we need to know ourselves, we need to feel peace within ourselves; the real peace does not exist anywhere. It's inside us and is the real navigation of life. We all need to develop our own understanding and then do whatever we can to increase the conscious awareness of humanity, so we can come together and tackle the issues that are surrounding us.

The effect of 'self' in decision-making process cannot be underestimated. If we examine the characteristics of decisions in our own life relating us to external agencies (other than self) 
our beliefs, faith and thoughts influence them. A few combinations of our character with character of decisions are Intolerant Leader - Aggressive Decisions, Materialistic MotivesWealth Accumulation, and Compassionate - Social Values. The western theories explained the source of ethical decisions as 'moral principles' (deontology) and 'good results' in concrete real world context (consequentialism). But, in Virtue Ethics, referred back to Aristotle, explained the quality of decisions as the outcome of personal traits. Philosopher Elizabeth Anderson defined the rationality as actions that represent a person's attitude toward people and other intrinsically valuable things. Hence, the decision of a person also reflects his/her attitude, character, work ethics, concerns, and commitments to others.

With ever increasing technological know-how, it seems to be most unsure of what is ultimately worth doing---- this suffices expectations from the business leaders. Spiritual intelligence is a measure of spiritual correlation to both Emotional Quotient and Intellectual Quotient (IQ). Spiritual intelligence (SQ) is the ability of a person to behave with wisdom and compassion to maintain both inner and outer peace irrespective of circumstances (Stephen, 2004). Spirituality is not about religion, neither is about god or rituals; a principled way of life, an attitude, a philosophy towards leading simple dedicated life on the earth seeing everything in equal terms.

\section{Spirituality in Leadership}

A leader is a fulcrum in exchange of values in between the internal and external environment. He navigates the organization through external opportunities using the internal capabilities. He derives the strategies to make internal resource matrices to maximize the gains of all transactions. In the internal resources, the 'Manpower' is the active resources while the 'customer' is the active external resource. Hence, the spirituality in the leader prompts to give more importance to human values to pacify both employees and customers; it also prompts to reduce the threat on external environment as well.

\section{The Religious Effects on Spirituality of Leaders}

The religion of a person stands for the faiths and beliefs s/he keeps and gets reflected on behaviours and decisions which transcend from the commune living across the spectrums. Based on religious approach, we can see three types of people - theist, atheist and only materialistic; the theist ones, according to the doctrines of the religions, belong to and stand for the welfare of people and hence, they are naturally compassionate, caring, sharing and upholding human values. This motivates his workforce sumptuous and results in consistency in performance, lower employee turnover, and high degree of involvement in job as well as organizational development, and learning process.

From the perspectives of different isms, spirituality stands for the characteristics and traits of 'Man' and his positive development. The 'inclusiveness' principle encourage the managers to respect all employees in the same level though there is diversity in culture or beliefs or faith; the servant cultism, professes inclusiveness; and the doctrine of helping the needy and caring for others. The great Indian spiritual mystic Sri Ramakrishna Paramahamsa explained the religions as different paths to one God and all religions stand for the welfare of people; he practiced several religions, including Islam and Christianity, and taught that in spite of the 
differences, all religions are valid and true and they lead to the same ultimate goal — God. He devoutly repeated the name of Allah, wore a cloth like the Arab Moslems, said their prayer five times daily, and felt disinclined even to see images of the Hindu gods and goddesses, much less worship them - for the Hindu way of thinking had disappeared altogether from my mind. After three days of such practice he had a vision of a "radiant personage with grave countenance and white beard resembling the Prophet and merging with his body". Hence, the spirituality in business stands for fairness and transparency in every transaction, care and support to employees, and care for the environment benefitting all stakeholders.

In the case atheist, he evaluates the cases based on truth, ethics, justice, and logic and reasoning. The decisions will be unbiased and focus on organizational growth. The managers with materialistic approach evaluate the situations based on monetary gains alone; here, the focus is profit irrespective of any circumstances. These managers can be a catalyst of high organization growth financially.

\section{Edifice of Spirituality}

The decoding of the word SPIRITUALITY provides us nine principles of Management and Leadership:

\section{$\checkmark$ S: Service $\quad$ : Totality in Service of All}

\section{$\checkmark$ P: Process : Passage of life}

$\checkmark$ Three 'I' reflect three distinct values: Integrity, Inner Voice and Inspire.

Integrity of character, Inner Voice is the stairway to spirituality as it always guides us to do what is right, to live by our conscience and by values; following this stretch is inspirational for us and others as well.

$\checkmark \quad ' \mathbf{R}$ ' is to read and learn to smell the roses on our way. We will never feel that we are ever in the midst of a storm. Every situation can then be faced with equanimity and fortitude.

$\checkmark \quad$ 'T' stands for transcendence, so let's transcend with inner reflection, meditation, yoga, self-control and compassion; if we practice these creative ways of looking at life, we will surely attain tranquillity and be at peace with ourselves.

$\checkmark$ ' $\mathbf{U}^{\prime}$ is all about the Universality and oneness of humankind; on realizing this, increasingly we are able to brush aside prejudices.

$\checkmark$ ' $\mathbf{A}$ ' is for acceptance; accept ourselves and others unconditionally, also it entails the total negation of arrogance.

$\checkmark \quad$ ' $L$ ' reminds us to have the largeness of heart to remember only the goodness of people and blanket out any pain or hurt that is encountered in varying degrees of relationships. The past and future are of no relevance as we cannot control or predict either; most important, learn to travel light. The Moment is now, life is too short, so let's cherish every moment.

$\checkmark \quad$ ' $\mathbf{T}$ ' the second last letter in spirituality, stands for Trust; we can't connect the dots looking forward; we can only connect them looking backwards. So we have to trust that 
the dots will somehow connect in our future. We have to trust in something - our gut, destiny, life, karma, whatever. This approach will never let us down, and it will make all the difference in our life."

$\checkmark \quad$ 'Y': the last letter stands for you and for me, too; only YOU can make this happen.

Significance of Spirituality in Organization Level

The market competition is severe in all sectors and hence, every firm concentrates on contraction sustain resource usage or cost on resource and to maximize the revenue generated. The changes in market are also very fast and hence, the sustainability depends on how fast you respond to the market changes. The firms are compelled to retain the loyal customers, maintain high quality in product and service, and maximize to promote the switch over from weak brands to own brands and to optimize the return on investment. This compels the employees for the multi-tasking and perpetual changes and overloading. Hence, the spirituality of managers brings confidence among employees through morale boosting strategies, incentives and training to optimize competency.

\section{Spirituality Leadership Theory (SLT)}

Spirituality Leadership Theory (Fry, 2003) had explained the "Spirituality" as the 'Self-Transcendence' and the attendant feeling of interconnectedness. A spiritual leader motivates his followers to bind to common purpose of 'Salvation' through a systematic process of devotion, commitment and altruistic love. In the same way, the spiritual leadership creates a special higher level bondage among the employees to contribute to the organization (intrinsic motivation) and develop a value- laden and ethical leadership and system (Sweeny and Fry, 2012).The relationship between the leader and the follower is expressed as a conceptual model including boundary conditions and moderators like narcissism, pro-social motivation to lead (MTL), follower's perceptions of leader integrity (ethics), and perceived organizational support (POS) (Krishnakumar et al., 2014).

The alternative definitions of spirituality together can be given as

1. Religious principles in work place as common practices (Hicks, 2002)

2. Heed to fight for existence in individual and organizational level ( Krishnakumar \&d Neck, 2002)

3. The feel of wholeness and strong inter-relatedness (Tanyi, 2002)

4. Upholding ethical and moral values (Dent et al., 2005)

The slogans like "Work is Worship", "Committed to Quality", "Born to be the Leader", "Thinking True, Acting Correct, Getting the Best" are really goal-oriented and motivating to achieve a general objective, may be "Wholeness in Direction" or quality or reducing waste or to create a common target, to be the leader in a segment, may be geographical, or political or in technology or in market.

Benefits of Spiritual Leadership 
No Conflict of Authority and Responsibility

There are two ways to avoid conflict between authority and responsibility

Definition, distribution and evaluation of authority and responsibility with the organization based on an organizational structure; the activities are documented and evaluated at all levels through audits. The implementation of Enterprise Resource Planning software has helped to minimize the conflict of hierarchy.

Sharing the work based on consciousness in each level: it is like the sharing of work in the kitchen. If the mother-in- law does one job, daughter-in-law takes another job yet to be done and daughter does another; but if the work is done by a maid, the family members withdraw from kitchen and whatever the maid does, the remaining work will be shared among the family members.

The latter will be a spiritual formation if the maid is given equal value as one of the family members. Even though the hierarchical diversity exist in spiritual set up, it will be only for the authority and professionalism for doing the work, but the interconnectedness, caring each other and altruistic love among employees develop wholeness to face any external challenge

\section{Servant Leadership}

This is a spiritual concept derived from all religious faith. The preaching of Jesus Christ "Those who want to be a leader must be servant to all" and "whatever you do for these little ones in my name is done for me". This reduces the power distance in the organization and tries to do justice to all employees. A manager is to do a scavenger job in an organization, the difference in position, status and power difference dissolves and the saying, "all are equal before God".

While servant leadership is a timeless concept, the phrase "servant leadership" was coined by Robert K. Greenleaf in "The Servant as Leader", an essay that he first published in 1970. In that essay, Greenleaf said:

"The servant-leader is servant first... It begins with the natural feeling that one wants to serve, to serve first. Then conscious choice brings one to aspire to lead. That person is sharply different from one who is leader first; perhaps because of the need to assuage an unusual power drive or to acquire material possession. The leader-first and the servant-first are two extreme types. Between them there are shadings and blends that are part of the infinite variety of human nature.

"The difference manifests itself in the care taken by the servant-first to make sure that other people's highest priority needs are being served. The best test, and difficult to administer, is: Do those served grow as persons? Do they, while being served, become healthier, wiser, freer, more autonomous, more likely themselves to become servants? And, what is the effect on the least privileged in society? Will they benefit or at least not be further deprived?"

A servant-leader focuses primarily on the growth and well-being of community people to which they belong. While traditional leadership generally involves the accumulation and exercise of power by one at the "top of the pyramid," servant leadership is different; the 
servant-leader shares power emphasizing the need of others first and helps people develop and perform as qualitatively as possible.

\section{Moving Away from War-Front Syndrome}

In the competitive market, all companies are struggling to position themselves and to increase their market share through price war. The strategies like Six Sigma, TQM, TPM and Quality Circle are a few religious models in which each employee religiously follows the system of procedures and methods to get the outputs within the framework of quality standards. This is a trade off between price qualities and the strategies for keeping a balance between qualities, economies of scale, and price are of religious in character as the believers must do in worship places; it is like the commanding order in the military system.

The religious leadership is different from the spiritual leadership. In most of the organizations, religious leadership is more effective in which the system is highly disciplined, and all employees follow them and the practice becomes habitual. Most of these practices are repetitive and redundant. Here, there are no emotional linkages with fellow workers or with the organization or job. There is no significance of individuality; it is easy to transform a religious organization to Automated System as the system is independent of efficiency or competence of the employee but depend on how he accustoms to the system and technology. In the spiritual organization it is totally opposite in practice than the religious system.

\section{Emergence as Learning Organization}

A learning organization accepts the ideas from the employees and then analyzes them to transform to a system or technology or strategy. In this, inclusiveness, or the interest of the organization to include the idea of employees at all levels is important; new product ideas, corrections and modifications in the system, forecasting the trend in consumer pattern, cost reduction strategies etc can be suggested from the experience of employees. It is a virtual intelligence system to adapt market changes. A marketing or sales person is finding a new business idea from the existing demand gap and s/he presents in the learning organization. The technical and management teams analyze the viability and they modify the system to adapt the new changes. The non-profitable products or services can be replaced with new products.

Bottlenecks in Developing Spiritual Organization and the Challenges to Sustainability: Results of Empirical Research in SMEs in India

\section{The Characteristics of Top Management}

The development of spiritual leadership depends on management choice. The managements prefer systematic reporting system and to function within a frame work. The documentation will be easy; the control of work-force size based on market demand is possible by termination or contract labour system. If the emotional bond exists it will be difficult; hence, the management wish to reduce the significance of individuality in the system.

\section{Size of the Firm}

The spiritual leadership is ideal for small enterprises. As the organization grow to the 
expansion level with multiple location businesses, the operational strategies will be religious than spiritual to retain control. Hence, if the management has to implement spiritual leadership in an organization it can be done through training and development. The spiritual leadership is a strategy to develop an orientation to the mission and vision of the organization through employee participation and engagement. Hence, the managements have to prepare themselves to implement the spiritual leadership in such a way that each employee feels proud to be a part of the organization for both internal care and brand equity. The best practice is to choose a hybrid strategy including the best practices of religious leadership and spiritual leadership. The negligence to individuality in the religious system will be replaced with interconnectedness and inclusiveness to develop a successful spiritual leadership.

\section{Complexity in Management}

The complexity in management arises due to the opaqueness of communication within organization. In such firms, informal communication system is prevalent and information asymmetry exists. In small enterprises it is common; the non-availability in historical data leads to experiential decision making process. The lack of data leads to misunderstanding and conflict among stake holders. The spiritual leadership will build confidence among its employees through their involvement in strategically issues. Developing ethical practices, morality, respect to each other, minimizing gender inequality, promoting transparency through systematic documentation, and feel of wholeness within organization can transform it to a firm with spiritual leadership. Give and take is the theory of sharing that the management has to develop among its employees.

\section{Power Distance}

The power-distance of top-management is a devilish attitude that creates a multi-lateral layers within the organization and it may lead to the increase in complexity in management. All the positions and status within the organization is weighed with value of money invested or generated. But the value of output shown by the top-management is the total of contribution of each employee, whether it is direct or indirect. The role of scavenger in an organization cannot be ignored as he is hygienist to create a healthy environment for all in the work place. In an organization with power distance, a scavenger cannot access to the top-management. We neglect his opinions to improve hygiene in the work place. The power distance is one of the cause in opaqueness to information flow.

The spiritual leadership has only one plane as all in the organization, whether the top management or scavenger. The saying that "the earth will never rise in front of a king to respect him or go down in front of a beggar to insult him" is true in spiritual leadership. Both the king and the beggar walk in the same plane as the beggar and king are alike for the earth. Hence, the power distance is an imaginary egotism that differentiates employees psychologically and financially. The spiritual leadership ensures involvement of all in developing ideology of the organization though their value, quality and quantity vary with position.

\section{Favouritisms and Disparity}


Favouritism and Disparity is an evil in an organisation when personal preference or obligation of a top-manager to a sub-ordinate reflects in work places when perks are offered. The favouritism is misunderstood with variation in weight age of contribution of different employees in many occasions. The contribution of employee to the organization may not match with the number of years in an organization or years of total experience. The weight age varies from time to time with the worth of the employee's contribution. In a spiritual leadership, the effect of favouritism and disparity will be diluted with altruistic love that each employee appreciate the other for the achievements and realise the fact that "We live today, we earn from what we do today".

\section{Failure in Succession}

Failure in succession is a challenge to sustainability of any organization. In a normal organization, succession is the transfer of responsibility and authority that cannot be shared by anyone. The strategies will vary with the ideologies of that person. If there is difference in ideologies between the former and the successor, then the decision making process.

But, there is no religion stopped due to the succession failure till now. This is the peculiarity of spiritual leadership. There is no difficulty in leading a committed and emotionally bound society and all the functions will be done in a religious way. The concept of Pull-Push happens here. The leader pulls the organization to direction and all the employees push it to that direction itself. If the organisation is working on a long term vision, then succession will not be a challenge. The orientation to a common goal makes the succession effortless.

\section{Difficulty in Managing Multiple Objectives}

The spiritual leadership is an effective tool to divert the internal HR capital to multiple directions; this is needed when the organization is looking for expansion and diversification.

\section{The Laws of Organizations}

JRD and Ratan Tata were much more soft spoken and very much consensus leaders. They used their own initiative when solving problems and creating value and profits for their business; no one has to lean over their shoulders, no one has to drive them. Drucker used a curious phrase 'to create a customer' meant businesses have to go out and seek potential customers and make them aware of the goods and services that they can offer and the value to be added to their lives over and above the cost of purchase.

\section{Spirituality in Business}

Why corporate scandals and wrong governance took place and norms and standards sprouted around the globe, norms for the listed companies when everything is in place in the Indian ethos. Why sheer greed of Lehman Brothers led to their catastrophe when the old dictum 'earth provides enough to satisfy every man's need but not every man's greed' still holds well today and now.

Anything depends on the spirit in which it is done, the principles on which it is built and the use to which it is turned. This triune law of spirit-principles-use is the crystallization of spirituality in business which can be treated as the benchmark to judge the present-day 
dominant wave in the realm of economic function.

Looking at the leadership from a spiritual perspective has been something experiential. Such leaders are conscious higher than that of the body-mind cantered state coupled to live more and more in the same psyche. The transformed one in the sense psycho-philosophy is the gradual process to the state of consciousness which is holistic, non-egoistic and hence flawless.

\section{This Real Business Edifice}

With the above edifice, there was the research quest to explore the functioning of top corporate icons to know how ethical are they, how spiritual is their attitude towards their work and how do they assimilate spirituality into their profession very scientifically without any confusion. Here in, we have to act with the caution that the scientific-tech eras at the existential level are more panicky and fearful than ever before. Natural simplicity and trust now stand replaced with technological complexity, coupled with mounting threat and fear. Hence, our exploration is very simple from the point of view of genuine transformed leaders who really act as role model for all sundry. Not necessarily the computing era has made the business better, that alongside tremendous advances in the field of scientific-tech, deterioration of the moral standards in every walk of life is worrisome and has enveloped business domain too.

\section{Behavioural Approach to Business by their Leaders}

This is about decisiveness of the leaders with conviction, amid ambiguity, with incomplete data and even unfamiliar domains to set clear priorities. Here to add, spirituality train us to be decisive because the answer come crystal clear from within the conscience. May be one is smart but a slow decision maker which leads to frustration among followers, attrition of valued talents, and even becoming over cautious. The answer is decision with time and conviction because a wrong decision is often better than no decision at all; corrections can be made any time to get the right answer.

For a decisive leader how to develop understanding of the followers to drive for performance and align them around the goal; it's nothing but engaging a key team to move along and ultimately they train others to realize the details.

Once in 1970s there was a clarion call from the Mother of Sri Aurobindo Ashram as" The world is preparing for a change so prepare yourself to accept such change or else it will be thrust upon you" which means to adapt with showing pro-activeness and adjust with the changing circumstances; here again spirituality plays a dominant role for the leader to attend to the call of the conscience. A business leader has to look long term, sense and change early and then make strategic moves to take advantage of it.

\section{Effect on Practicality by the Business Leaders}

* Ideas on promoting spirituality in the workplace: being down to earth leader; doing business based on trusteeship; accord employee satisfaction top priority; being humble as a leader. 
* Bring the element of spirituality into the leadership: being trustworthy to all; acting as a task master with humane approach; with personal involvement; respecting one and all

* Belief in nurturing spiritual side of leadership to exhibit supportive behaviour towards subordinates: delegation of work to be the top priority; true nurturing of subordinates; punishing the subordinate tough in case anything wrong happens

* About transformational leaders: such example(s) to be emulated; should be trusted with more responsibility; they need to nurture others in the same direction

* Specific changes to be fostered in the organization because of spiritual faculty of leadership-personality: a win-win situation for all; employee morale at high; increase in productivity.

\section{A Note on the Word "Yoga"}

Yoga has two different meanings - a general meaning and a technical meaning. The general meaning is the joining together or union of any two or more things. The technical meaning is "a state of stability and peace and the means or practices which lead to that state." The scriptures use the word with both meanings.

\section{Essentials for Management Education: The Crux of Spirituality}

In any management education, the key part is knowledge; the others are skill and attitude. The management in the West contributed a lot towards knowledge and skill development, theories and frameworks and so on. Most of the management books are from authors from the US so different skills such as negotiation, analytical, mathematical modelling and pedagogical methods like case studies were brought in. Spirituality in Management facilitates the core of that Inner Self the management of which leads to perfection in any managerial role. The B-Schools while trying to teach the concept of Management have to focus on Self Management resorting to spirituality. The Indian context of Yoga is Union with the Supreme Divine so that a manager manages the whole gamut of all affairs with dedication and surrender with thrust on spirituality.

\section{Copyright Disclaimer}

Copyright for this article is retained by the author(s), with first publication rights granted to the journal.

This is an open-access article distributed under the terms and conditions of the Creative Commons Attribution license (http://creativecommons.org/licenses/by/4.0/) 